UDC 332.025 .12

UAC code 08.00 .05

\title{
Improving government support for small agribusiness due to the COVID-19 coronavirus pandemic
}

\author{
A. A. Alekseev ${ }^{1 凶}$, O. A. Ruschitskaya² ${ }^{2}$ V. N. Lavrov², N. A. Yurchenko² \\ ${ }^{1}$ Surgut State University, Surgut, Russia \\ ${ }^{2}$ Ural State Agrarian University, Ekaterinburg, Russia \\ E-mail: break-fast@mail.ru
}

Abstract. Purpose of the study is improving the mechanism of state regulation of agricultural producers, due to the need to overcome the pandemic and prevent the recurrence of similar scenarios in the future. The object of research is an agricultural producer, belonging to the category of small business. The subject of the study is the relationship between the object of study and the state represented by government bodies and institutions involved in the provision of state support that may arise in the process of overcoming the consequences of the COVID-19 pandemic. Research Methods. A theoretical analysis was used to identify threats from the coronavirus pandemic to agriculture and the agro-industrial complex as a whole. Comparison as a method of cognition was used when comparing the requirements of small businesses for state support and measures actually taken by the government. A systematic approach and modeling were used to summarize the experience of the functioning of the economy in a pandemic and to create patterns of behavior of small agribusiness entities. The method of scientific abstraction made it possible to present the most probable state of small business in the agro-industrial complex, depending on the provision or refusal of state regulatory influence on the economy in order to eliminate the damage caused by the pandemic. The rule of combining historical and logical in their unity allowed us to look at the coronavirus pandemic not as a unique phenomenon in the history of modern economics, but as a negative phenomenon that will potentially be reproduced in the future and the logic of counteraction which requires active intervention at the state level, and in the future - generalization, analysis and improvement of the experience gained. The theoretical and methodological basis of the study is composed of statistical data on the state of the world economy, consumption, unemployment, publications of news agencies and government officials on measures taken to deal with the consequences of the pandemic, existing programs for the development of the digital economy, as well as publications of leading scientists in the agricultural sector on digital problems economics. Results. Within the scope of this study, there were characterized the most negative consequences of the pandemic for the agro-industrial complex, there was carried out the analysis of announced and already taken measures to support entrepreneurship and were described behavior models of small agribusiness entities in the current situation. Scientific novelty. The authors have developed a new method for the rapid diagnosis of a small agribusiness subject, claiming to receive state support for regional and industry programs.

Keywords: pandemic, coronavirus, agribusiness, digital economy, government support, government regulation.

For citation: Alekseev A. A., Ruschitskaya O. A., Lavrov V. N., Yurchenko N. A. Improving government support for small agribusiness due to the pandemic of the coronavirus COVID-19 // Agrarian Bulletin of the Urals. 2020. No. 04 (195). Pp. ... DOI: ...

Paper submitted: 08.04.2020.

\section{Introduction}

The digital transformation of the Russian economy at the time of the onset of the COVID-19 coronavirus pandemic was in an active phase, but was not completed. The pandemic damage has affected almost all sectors of the economy. The agricultural sector was no exception.

In such conditions, there was an objective need to improve the mechanism of state regulation of the economy, to improve the selection procedure for small agribusiness entities - potential recipients of state support. At the same time, not all representatives of small business behaved adequately to the current situation. Models of their behavior need to be generalized in order to select the most effective and suitable for providing limited state support.

\section{Methods}

The purpose of the study is to improve the mechanism of state regulation of agricultural producers, due to the need to overcome the pandemic and prevent the recurrence of similar scenarios in the future.

The logic of the study required solving the following problems: to highlight and describe the most threatening to the agro-industrial complex consequences of the coronavirus pandemic, analyze the declared and already taken measures to support entrepreneurship, identify typical patterns of behavior of small agribusiness entities in the current situation and, based on the above, develop a new method for express diagnostics of a small agribusiness entity that claims to receive state support within the scope of regional and industry programs. 
It is important to understand that from an economic point of view, it is not the coronavirus itself that poses the threat, but the reaction to it. Viral infection is not able to harm physical capital, and the change in supply on the labor market (at the current level of morbidity and mortality) is at the level of statistical error. At the same time, certain agricultural sectors temporarily lost the cheap labor of labor migrants, the movement of which was actually suspended. In general terms, the greatest threat to the agro-industrial complex is represented by individual measures to counteract the spread of coronavirus, as well as changes in consumer behavior.

The fall in demand for agricultural products caused by a decrease in the purchasing power of consumers. The China Caixin Services Purchasing Managers Index (PMI), which is based on sales, employment, inventory, and prices of more than 400 private companies, was 26.5 for the first time in 15 years, although it usually did not fall below 50 points [1]. A similar drop in consumption is observed in the world's largest US market. A fall in entrepreneurial income means lower wages and higher unemployment. This, in turn, means a significant reduction in consumer spending, including retail, cafes and restaurants, home delivery. For large agricultural holdings, this will lead to a decrease in sales volumes and a drop in profits, which will negatively affect their activities, but it hardly means bankruptcy. For a small agribusiness that operates with a small amount of working capital and has virtually no strategic reserves, a significant drop in sales can lead to loss of business, ruin and, therefore, to its liquidation.

Deteriorating credit conditions. One of the results of the pandemic is the deterioration of global economic growth forecasts developed by international organizations and rating agencies. For example, the Organization of Economic Co-operation and Development lowered the forecast for global economic growth from $2.9 \%$ to $2.4 \%$ [2]. In such circumstances, banks are moving to a more restrained lending policy, which means an increase in interest rates and a decrease in the volume of loans. This will lead to a slowdown in the technical re-equipment of agricultural producers and the inability to quickly replace failed equipment with new one. The introduction of new digital technologies in the face of the impossibility of borrowing is also at risk.

Gaps in production and supply chains. As a result of movement restrictions, the delivery time of fertilizers, pesticides, agricultural equipment and components for it slowed down. The seasonal movement of labor migrants is also impossible. Restrictions in this area can be maintained by governments of different countries for an indefinite period even after the actual end of the pandemic.

Tourism reduction. Tourism is one of the largest sectors of the world economy with a huge number of people employed in this area. The restrictions imposed on freedom of movement and the number of people simultaneously staying in one place led to huge losses for the restaurant, hotel and transport business. Even after the restrictions are lifted, many people will be wary of visiting other countries and regions because of the risk of infection. In such conditions, there arise objective prerequisites for the development of local tourism, including rural tourism. It is believed that the development of rural tourism leads to the creation of new jobs, additional opportunities for income in rural areas and thereby reduces the outflow of active population to cities [3, p. 12].

But existing agro-tourism facilities and rural infrastructure may not cope with the increase number of tourists. Consequently, there is a need for state support of agritourism and an increase in the cost of developing rural infrastructure.

Various measures to support entrepreneurship have been declared and implemented to counteract the negative consequences of the coronavirus pandemic.

The President of the Russian Federation V.V. Putin set specific tasks to support business:

provide a deferral for all taxes, with the exception of VAT, for six months for medium and small enterprises;

for enterprises that find themselves in a difficult situation, there is introduced a six-month moratorium on filing applications from lenders to recover fines;

- the government is tasked with monitoring the situation and expanding the list of industries in need of support; reduce insurance premiums for small and mediumsized enterprises to $15 \%$ if the salary of employees is above the minimum wage [4].

Prime Minister M. V. Mishustin signed an order of the Government of the Russian Federation dated March 18, 2020 [5], according to which the Federal Tax Service, the Ministry of Finance, the Ministry of Economic Development, the heads of the highest executive bodies of state power of the constituent entities of the Russian Federation and the Central Bank must implement a number of measures aimed at providing a deferment in the payment of taxes and insurance contributions in respect of business entities from industries, most affected by coronavirus infection.

It is also necessary to prepare a procedure for introducing a moratorium on filing bankruptcy petitions against persons who are in arrears to budget organizations.

Sberbank of Russia will transfer loan payments for borrowers most affected by the coronavirus industries. The program provides the transfer of payments in the second quarter of 2020 to a period of October 1, 2020, and for hotel and retail real estate clients, who have felt the consequences of the pandemic most severely, until the termination of the loan agreement [6]. The support program from Sberbank extends to services, rental of hotel and retail real estate, trade, work of educational institutions, sports, culture and art.

The Bank of Russia has announced its intention to implement a number of measures aimed at the activities of credit organizations. Until September 30, 2020, it is planned to redistribute the regulatory impact on credit organizations working with travel and transportation companies, manufacturers of medicines and medical equipment. Credit organizations have the right not to change the rating of the quality of loan servicing, regardless of the financial situation of borrowers from these sectors [7].

The Ministry of Agriculture has developed a number of measures aimed at restricting the export of cereal crops. A quota of 7 million tons was established for the export of wheat and meslin, rye, barley and corn, with the exception of seeds of grain crops, for a period from April 1 to June 30, 2020. Preparations are underway for commodity interventions, taking into account the established price caps for 2020-2021 [8]. 
On the part of the business community, the requirements for the content of measures to support small businesses were formulated by Anastasia Tatulova [9], the founder of the "AnderSon" family cafe network:

- $\quad$ interest-free loans and subsidies for businesses after quarantine for a year;

- exemption from payment of cadastral tax and land tax to lessors who have lost their rent;

- credit amnesty for entrepreneurs of all affected sectors that previously had no late payments;

- cash grants for small and medium-sized businesses to pay rent;

guarantees of non-use by the state of punitive measures for the actions of entrepreneurs aimed at overcoming the current crisis situation;

- changes in tax regimes for affected industries;

- VAT up to a maximum of $10 \%$ for all affected industries.

These measures relate to two areas of support: direct (in the form of gratuitous financial assistance) and indirect (in the form of tax regulation). In our opinion, these measures are redundant. Moreover, they distort the very essence of entrepreneurial activity and the market mechanism. An entrepreneur is personally responsible for his decisions, and if he has not prepared his business for a change in the economic situation, then he is an inefficient entrepreneur and must leave the market. In February 2020, Russian entrepreneurs, instead of preparing for a pandemic, bought premium cars whose sales grew by $16 \%$ [10]. State support of these particular entrepreneurs is detrimental to the business environment as a whole.

Small business is inherently highly risky; the process of the emergence of new entities and the disappearance of old ones is a specific feature of a market economy. The task of the state, according to the authors, is not to support specific entrepreneurs at all hazards. The development strategy of small and medium-sized enterprises in the Russian Federation [11] involves the development of primarily mass and high-tech entrepreneurship by creating conditions for their optimal development. Based on this, the authors believe that the regulatory influence of the state on the market, even in a pandemic, should be carried out in accordance with the laissez faire principle. The main directions of state participation in saving the economy should be the transformation of mechanisms for providing state support and improving market infrastructure, taking into account new challenges. The pandemic in this particular case has become a trigger for the long overdue transformations of the economic system.

\section{Results}

The digital transformation of the Russian economy, carried out as part of the national program "Digital Economy of the Russian Federation" [12], gave a powerful impetus to the development of the domestic economy, comparable to the industrialization of the 1930s. The purpose of the departmental project "Digital Agriculture" is the digital transformation of agriculture through the introduction of digital technologies and platform solutions to ensure a technological breakthrough in the agricultural sector and to achieve productivity growth in "digital" agricultural enterprises [13]. It also postulated specific tasks, the solution of which is necessary to achieve this goal, and the need for government support is recognized, for example, by introducing the SMART-contract system [14, $p$. 47].

The current situation in the world can be described as stressful. Perhaps such assessment is even too soft. Even if this stress does not escalate into a global economic crisis, changes must be made in Russian economic policy aimed at increasing its stress resistance in similar situations. In particular, approaches to the provision of state support for small business and youth entrepreneurship in the agricultural sector should change. The priority of providing state support should not be assistance to specific business entities, but the regulatory impact on the agricultural products market in order to digitally transform it. Summarizing the experience of the economy functioning in a pandemic, the authors identified several patterns of behavior of small agribusiness entities:

1) the "depressive" model is characterized by the suspension of business activity or doing business in violation of the restrictions and prohibitions. The functioning of a small business within the framework of this model with a high degree of probability leads to bankruptcy as a result of losses or fines;

2) "passive-aggressive" model, when the entrepreneur does not independently try to save his business, but requires help from society and the state;

3) the "survival" model, in which the business loses the profit received earlier from traditional sales, but tries to organize remote reception of orders (via phone and social networks) and delivery of goods (by couriers, taxi, transport companies);

4) the "lucky" model, which includes small businesses that were initially focused on digital commerce, received an unexpected increase in the number of orders and strengthened their market position;

5) the "transformer" model, which describes the activities of enterprises that practiced traditional and online business activity before the pandemic and compensated for losses due to digital sales of products.

The authors believe that the regulatory impact of the state on the agro-industrial complex in the interests of overcoming the pandemic and preventing the recurrence of similar scenarios in the future should be as follows:

- $\quad$ state support for small agribusiness entities operating within the framework of "surviving", "lucky" and "transforming" models;

refusal to support "depressed" and "passively aggressive" small agribusiness entities as unpromising;

- development of digital infrastructure in order to stimulate the transition of entrepreneurs to modern formats of conducting agribusiness;

digital transformation of state support mechanisms, ensuring their smooth functioning even in adverse conditions; tightening control over the provision of state support funds in connection with the predicted deterioration of key macroeconomic indicators and the upcoming correction of the state budget.

As a result of the study, the authors developed a new method for express diagnostics of a small agribusiness subject, claiming to receive state support in the framework of regional 
Table 1

Express diagnostics of a small agribusiness subject applying for state support

\begin{tabular}{|c|c|c|c|c|}
\hline \multirow[b]{2}{*}{ No. } & \multirow{2}{*}{ Evaluation Criterion } & \multicolumn{3}{|c|}{ Rating score } \\
\hline & & 2 points & 1 point & 0 points \\
\hline 1 & $\begin{array}{l}\text { Does the enterprise need the work of foreign } \\
\text { citizens (labor migrants)? }\end{array}$ & No (not needed) & Needed, but not required & Is required \\
\hline 2 & $\begin{array}{l}\text { Is remote reception and processing of orders } \\
\text { possible? }\end{array}$ & Yes (online) & $\begin{array}{c}\text { Yes, as you access the da- } \\
\text { tabase }\end{array}$ & No \\
\hline 3 & $\begin{array}{l}\text { Can an entrepreneur arrange delivery of } \\
\text { products to consumers? }\end{array}$ & Yes (on my own) & $\begin{array}{l}\text { Yes, with the involvement } \\
\text { of transport companies }\end{array}$ & No \\
\hline 4 & $\begin{array}{l}\text { Can an enterprise conduct financial activi- } \\
\text { ties through online banking? }\end{array}$ & $\begin{array}{c}\text { Fully capable of } \\
\text { switching to cashless } \\
\text { payments }\end{array}$ & $\begin{array}{c}\text { Yes, but there are techni- } \\
\text { cal limitations }\end{array}$ & Cash critical \\
\hline 5 & $\begin{array}{l}\text { Does the product packaging meet the new } \\
\text { sanitary and epidemiological requirements? }\end{array}$ & \begin{tabular}{|c|} 
Above the require- \\
ments of state standard \\
and can be further \\
improved on existing \\
equipment
\end{tabular} & $\begin{array}{l}\text { Above state standard } \\
\text { requirements }\end{array}$ & $\begin{array}{l}\text { Meets the require- } \\
\text { ments of state stan- } \\
\text { dard }\end{array}$ \\
\hline 6 & $\begin{array}{l}\text { Is the product of interest for public procure- } \\
\text { ment? }\end{array}$ & Yes & Yes, in some cases & No \\
\hline 7 & $\begin{array}{l}\text { Can the company in a short time reorient to } \\
\text { the release of socially significant products? }\end{array}$ & Yes, in a short time & Yes, in the medium term & $\begin{array}{c}\text { No, or conversion is } \\
\text { not practical }\end{array}$ \\
\hline 8 & $\begin{array}{l}\text { Is this enterprise able to maintain the volume } \\
\text { of production necessary for consumers under } \\
\text { conditions of restrictions on the import of } \\
\text { equipment, components, raw materials and } \\
\text { technologies? }\end{array}$ & Yes & $\begin{array}{c}\text { Yes, with loss of quality } \\
\text { and/or quantity of prod- } \\
\text { ucts }\end{array}$ & No \\
\hline 9 & $\begin{array}{l}\text { Is production of an enterprise important for } \\
\text { ensuring food security in Russia? }\end{array}$ & Yes & $\begin{array}{l}\text { No, but the company } \\
\text { is able to switch to the } \\
\text { production of important } \\
\text { products }\end{array}$ & No \\
\hline 10 & $\begin{array}{l}\text { Is an enterprise able to exist without govern- } \\
\text { ment support? }\end{array}$ & $\begin{array}{l}\text { Yes, but support is } \\
\text { needed at this stage }\end{array}$ & Maybe & $\begin{array}{l}\text { No, or high risk of } \\
\text { business disruption }\end{array}$ \\
\hline
\end{tabular}

Table 2

Interpretation of the results of express diagnostics of a small agribusiness subject applying for state support

\begin{tabular}{|c|c|l|}
\hline No. & Rating, points & \multicolumn{1}{c|}{ Recommendation } \\
\hline 1 & $0-5$ & State support not recommended \\
\hline 2 & $6-10$ & State support is provided only in the case of a large number of unallocated means of support \\
\hline 3 & $11-15$ & Government support recommended \\
\hline 4 & $16-20$ & State support is given priority \\
\hline
\end{tabular}

and industry programs. Express diagnostics can be carried out livelihoods, which led to a sharp reduction in demand for agby employees of the regional ministry (department) of agricul- ricultural products. In such circumstances, the eternal discusture, responsible for the distribution of state support funds, on sion about the need for state intervention in the economy was their own or with the involvement of external experts.

According to the results of express diagnostics, a small agribusiness entity can score from 0 to 20 points. Interpretation of the results of rapid diagnosis are presented in table 2.

The authors are aware that certain criteria have not previously been applied to small businesses. Their use became possible just after the pandemic was announced. World experience has shown that even a little help that an individual small business can provide is important and appropriate if it serves to preserve human life.

\section{Discussion and Conclusion}

The COVID-19 pandemic caused significant damage to the global economy, and the agro-industrial complex did not stand aside. Agriculture temporarily lost cheap labor (labor migrants), and a huge number of consumers were left without replaced by disputes about specific forms and methods of state support.

The authors previously proposed the introduction of a new direction of indirect regulation of the agro-industrial complex in the interests of the development of youth entrepreneurship, taking into account the spread of digital technologies and the need for their accelerated development by the agricultural sector - the digital transformation of government support mechanisms. In our opinion, this direction does not lose its relevance. Under the conditions of the pandemic, the regulatory impact of the state should be strengthened by measures to support entrepreneurs who have proven their effectiveness in crisis situations - farmers, agricultural engineers, and enthusiasts of the digital economy.

\section{References}

1. China Caixin Services Purchasing Managers Index (PMI) [e-resource]. URL: https://www.investing.com/economic-calendar/chinese-caixin-services-pmi-596 (appeal date: 04.04.2020).

2. Leading indicators and tendency surveys. Release of OECD [e-resource]. URL: http://www.oecd.org/sdd/leading-indicators (appeal date: 04.04.2020). 
3. Sel'skiy turizm kak sredstvo razvitiya sel'skikh territoriy: metodicheskoe posobie [Rural tourism as a means of rural development: methodological manual] / I. V. Lebedeva, S. L. Kopylova. Moscow : ARSI, 2018. 164 p. (In Russian.)

4. Putin V. V. Obrashchenie k grazhdanam Rossii [An appeal to the citizens of Russia] [e-resource] // Official site of the President of Russia. URL: http://kremlin.ru/events/president/news/63061 (appeal date: 04.04.2020). (In Russian.)

5. Poruchenie Pravitel'stva Rossiyskoy Federatsii ot 18 marta 2020 goda [The order of the Government of the Russian Federation of 18 March 2020] [e-resource] // Official site of the Government of Russia. URL: http://government.ru/orders/selection/401/39204 (appeal date: 04.04.2020). (In Russian.)

6. Sberbank pereneset platezhi po kreditam dlya naibolee postradavshikh otrasley [Sberbank will transfer loan payments for the most affected sectors] [e-resource] // Interfax: news. URL: https://www.interfax.ru/business/700904 (appeal date: 04.04.2020). (In Russian.)

7. Kommentariy Banka Rossii o vremennykh regulyatornykh poslableniyakh dlya bankov v svyazi s rasprostraneniem koronavirusa [Comment of the Bank of Russia on temporary regulatory exemptions for banks in connection with the spread of coronavirus] [e-resource] // Official site of The Central Bank of Russian Federation. URL: http://cbr.ru/Press/event/?id=6485 (appeal date: 04.04.2020). (In Russian.)

8. Pravitel'stvo RF odobrilo predlozheniya Minsel'khoza Rossii o vvedenii kvoty na eksport zerna [The Government of the Russian Federation approved the proposals of the Ministry of Agriculture of Russia on the introduction of quotas for grain export] [e-resource] // Official site of Ministry of Agriculture of the Russian Federation. URL: http://mcx.ru/press-service/news/ pravitelstvo-rf-odobrilo-predlozheniya-minselkhoza-rossii-o-vvedenii-kvoty-na-eksport-zerna (appeal date: 04.04.2020). (In Russian.)

9. Tatulova A. "Nam ostalos' neskol'ko nedel"": kak koronavirus ubivaet malyy biznes v Rossii ["We have a few weeks left": how the coronavirus kills small businesses in Russia] [e-resource] // Forbes.ru. URL: https://www.forbes.ru/karera-isvoy-biznes/395715-nam-ostalos-neskolko-nedel-kak-koronavirus-ubivaet-malyy-biznes-v-rossii (appeal date: 04.04.2020). (In Russian.)

10. Rossiyskiy rynok premial'nykh avtomobiley v fevrale vyros na $16 \%$ [The Russian market for premium cars in February grew by $16 \%$ ] [e-resource] // Analytic Agency “Autostat". URL: https://www.autostat.ru/news/43247. (appeal date: 04.04.2020). (In Russian.)

11. Strategiya razvitiya malogo i srednego predprinimatel'stva v Rossiyskoy Federatsii na period do 2030 goda (utv. rasporyazheniem Pravitel'stva RF ot 2 iyunya 2016 g. No. 1083-r) [The development strategy of small and medium-sized enterprises in the Russian Federation for the period until 2030 (approved by the order of the Government of the Russian Federation of 2 June 2016 No. 1083-r)] [e-resource] // Garant.ru. URL: https://www.garant.ru/products/ipo/prime/doc/71318202 (appeal date: 04.04.2020). (In Russian.)

12. Natsional'naya programma "Tsifrovaya ekonomika Rossiyskoy Federatsii" [The national program "Digital Economy of the Russian Federation"] [e-resource]. URL: https://digital.ac.gov.ru (appeal date: 04.04.2020). (In Russian.)

13. Vedomstvennyy proekt "Tsifrovoe sel'skoe khozyaystvo" [Departmental project "Digital Agriculture"] [e-resource] // Official site of Ministry of Agriculture of the Russian Federation. URL: http://mcx.ru/upload/iblock/900/900863 fae06c026826a9ee43e124d058.pdf (appeal date: 04.04.2020). (In Russian.)

14. Voronin B. A., Loretz O. G., Mitin A. N. [et al.] K voprosu o tsifrovizatsii rossiyskogo sel'skogo khozyaystva (obzor informatsionnykh materialov) [On the issue of digitalization of Russian agriculture (review of information materials)] // Agrarian Bulletin of the Urals. 2019. No. 2 (181). Pp. 46-52. DOI: 10.32417/article_5cb0b27b458600.04669366. (In Russian.)

15. Rushchitskaya O. A. O vliyanii tekushchego krizisa na razvitie rossiyskogo prodovol'stvennogo rynka [On the impact of the current crisis on the development of the Russian food market] // Agrarian Russia. 2016. No. 6. Pp. 29-33. DOI: 10.30906/19995636-2016-6-29-33. (In Russian.)

16. Latypov R. T., Maleykina G. P., Ruchkin A. V. Effektivnost' podderzhki krest'yanskikh (fermerskikh) khozyaystv v regione [The efficiency of support of peasant (farm) farms in the region] // Bulletin NGIEI. 2019. No. 9 (100). Pp. 109-118. (In Russian.)

\section{Authors' information:}

Aleksandr A. Alekseev ${ }^{1}$, postgraduate, ORCID 0000-0001-7984-0085, AuthorID 704706; break-fast@mail.ru

Olga A. Rushchitskaya ${ }^{2}$, doctor of economics, associate professor, head of the department of management and economic theory, ORCID 0000-0002-6854-5723, AuthorID 518696; ifim15@mail.ru

Vladimir N. Lavrov², doctor of economics, professor, professor, department of management and economic theory, ORCID 0000-0003-0990-2038, AuthorID 848398

Nadezhda A. Yurchenko², candidate of law, associate professor, department of management and economic theory, ORCID 0000-0001-7836-1592, AuthorID 1040037

${ }^{1}$ Surgut State University, Surgut, Russia

${ }^{2}$ Ural State Agrarian University, Ekaterinburg, Russia 